ISSN: 1858-4837; E-ISSN: 2598-019X

Volume 17, Nomor 1 (2022),

https://jurnal.uns.ac.id/region

DOI: 10.20961/region.v1711.34239

\title{
Kajian perkembangan ruang publik bersejarah di pusat kota (Studi kasus: Taman Sriwedari sebagai Kebun Raja di Kota Surakarta)
}

\author{
Study on the development of historical public space in the city center (Case \\ study: Taman Sriwedari as King's Garden in Surakarta)
}

\author{
N D Swastika ${ }^{1}$, I Aliyah ${ }^{1}$, dan G Yudana ${ }^{1}$ \\ ${ }^{1}$ Program Studi Perencanaan Wilayah dan Kota, Fakultas Teknik, Universitas Sebelas \\ Maret
}

Corresponding author's email: nikennds@gmail.com

\begin{abstract}
Abstrak. Kota Surakarta mengalami perkembangan pembangunan kota yang dipengaruhi oleh perubahan sistem pemerintahan. Hal tersebut masih dapat dirasakan melalui keberadaan aset-aset khususnya peninggalan bersejarah yang merepresentasikan beberapa masa pemerintahan. Taman Sriwedari merupakan ruang publik bersejarah yang berawal dari konsep taman kota (Kebon Rojo) pada masa pemerintahan Kasunanan Surakarta Hadiningrat, kepemimpinan Paku Buwono X pada tahun 1901. Kemudian hingga saat ini, kawasan Taman Sriwedari telah mengalami perkembangan pada penggunaan ruang yang cukup signifikan sejak pertama kali dibangun, salah satunya adalah pembangunan masjid raya yang sedang berlangsung sebagai salah satu upaya revitalisasi oleh pemerintah. Berkaitan dengan revitalisasi ruang bersejarah, penelitian ini bertujuan untuk mengetahui bagaimana Taman Sriwedari berkembang, antara lain; 1) perubahan penggunaan ruang, 2) fenomena yang melatarbelakangi, serta 3) bagaimana hal tersebut mempengaruhi aktivitas. Penelitian ini menggunakan metode penulisan sejarah dan pemetaan secara spasial dengan pendekatan naratif yang diinterpretasi dalam pembagian periode perkembangan, yaitu periode 1901-1945, periode 1946-1984, dan periode 1984-saat ini. Temuan menunjukkan penggunaan ruang dan aktivitas yang ada saat ini sudah berbeda dari konsep awal pembangunan Kebon Raja. Periode pertama menunjukkan Taman Sriwedari dengan konsep taman kota di bawah pengelolaan Kasunanan Surakarta Hadiningrat. Kemudian, periode kedua mulai terjadi perubahan dengan masuknya aktivitas komersial dan hilangnya salah satu atraksi ruang publik. Pada
\end{abstract}


periode ketiga perubahan fungsi-fungsi ruang semakin signifikan terkait dengan kebijakan kerja sama pihak ketiga (aktivitas swasta semi privat yang mulai menghilangkan fasad asli taman). Diharapkan penelitian ini dapat menjadi masukan dalam upaya pemerintah untuk menghidupkan kembali ruang publik bersejarah melalui revitalisasi tanpa mengabaikan karakteristik penggunaan ruang sebelumnya.

Kata Kunci: Bersejarah; Cultural Heritage; Perkembangan Ruang Publik; Perubahan Penggunaan Ruang

\begin{abstract}
The city of Surakarta experienced urban developments which was influenced by the changing of government system. This can still be recognized through the existence of the city's assets, specifically cultural heritage that representing several periods of government. Taman Sriwedari is a historical public space that originates from the concept of a city park (King's Garden) during the reign of Kasunanan Surakarta Hadiningrat, the leadership of Paku Buwono X in 1901. Then until now, Taman Sriwedari has undergone significant developments in space utilization since it was first established, one of which is the ongoing construction of the Great Mosque as one of the government's revitalization efforts. Regarding the revitalization of historic space issue, this study aims to find out how Taman Sriwedari developed, including; 1) changes in the use of space, 2) the underlying phenomena and 3) how these affect the activities. This research employed a historical method and spatial mapping with a narrative approach which is interpreted in terms of the division of development periods, namely the period of 1901-1945, the period of 1946-1984, and the period of 1984-present. The finding show that the current use of space and activities is different from the initial concept of King's Garden. The first period shows that Taman Sriwedari with the concept of city park under the management of Kasunanan Surakarta Hadiningrat, then the second period began to change with the entry of commercial activities and the loss of one of the public space attractions. In the third period, the space utilization is significantly changed because of the policy of third-party cooperation (the inclusion of many semi-private activities which began to change the original facade of the park). It is expected that this research can become part of government input to revive a historical public space through revitalization without ignoring the characteristic of the previous use of space.
\end{abstract}

Keywords: Change in Use of Space; Cultural Heritage; Historical; Public Space Development

\title{
1. Pendahuluan
}

Salah satu visi Kota Surakarta dalam Rencana Tata Ruang Wilayah Kota Surakarta tahun 20112031 adalah mewujudkan ruang kawasan budidaya yang terintegrasi antara nilai budaya dan lingkungan. Berkaitan dengan hal tersebut, pembangunan kota sudah semestinya diarahkan untuk dapat secara harmonis berdampingan atau sejalan dengan nilai budaya kota yang sudah terlebih dahulu eksis sebagai karakter kota. Keberadaan aset-aset cultural heritage, misalnya menjadi salah satu komponen keberhasilan kota dalam menjaga nilai-nilai budaya kota. UNESCO dalam Jokilehto [1] mendefinisikan cultural heritage sebagai seluruh bentuk material, 
baik artistik atau simbolik yang diwariskan oleh masa lalu kepada masing-masing kebudayaan dan seluruh umat manusia. Warisan budaya termasuk sumber dimana identitas budaya kita terbentuk. Budaya merupakan yang ada saat ini, oleh karena itu warisan budaya bersifat historis atau bersifat kesejarahan [2].

Ruang publik secara umum didefinisikan sebagai ruang terbuka yang dapat diakses oleh publik secara individual maupun secara berkelompok [3]. Dengan kata lain ruang publik menjadi sebuah ruang interaksi antar masyarakat kota melalui berbagai aktivitas yang dilakukan masyarakat di lingkungan ruang publik. Ruang publik merupakan elemen kota yang dapat memberikan karakter, memiliki fungsi interaksi sosial bagi masyarakat, kegiatan ekonomi, tempat apresiasi budaya, serta meningkatkan kualitas kota [4]. Taman Sriwedari dapat dikatakan sebagai pusat kebudayaan Jawa dengan berkembangnya berbagai aktivitas yang memiliki nilai tradisi, seni, dan budaya Jawa. Seperti yang dinyatakan Charter Of Public Space [5] bahwa ruang publik merupakan elemen kunci kesejahteraan individu maupun sosial, tempat bagi kehidupan kolektif komunitas, ekspresi perbedaan di dalam kesamaan, kekayaan alam dan budaya, serta dasar identitas mereka. Taman Sriwedari menjadi ruang kolektif dan interaksi individu dengan berbagai latar belakang budaya sejak masa penjajahan Belanda sampai dengan saat ini. Berdasarkan studi empiris Carmona, Magalhães, dan Hammond [6], dapat diketahui bahwa ruang publik memiliki berbagai fungsi, antara lain mengasah keterampilan sosial dan kognitif, mempromosikan kebersamaan dan kohesi sosial, menyediakan tempat untuk acara sosial, menyediakan tempat untuk pertukaran sosial dan untuk mendukung kehidupan sosial masyarakat, serta kesenangan (relaksasi, kontak sosial, hiburan, rekreasi, dan bersenang-senang). Keragaman aktivitas di Taman Sriwedari tumbuh menjadi sebuah sarana hiburan bagi masyarakat kota maupun daerah sekitar Kota Surakarta yang memiliki beberapa fungsi-fungsi demikian.

Pendapat Kostof dalam Dewi [7] menyatakan bahwa perkembangan ruang publik di beberapa kota dari masa ke masa dipengaruhi oleh kekuatan politik, ekonomi, sosial, lingkungan, serta teknologi. Secara politik Taman Sriwedari merupakan ruang publik yang dibangun pada masa pemerintahan Kasunanan Surakarta Hadiningrat di bawah kepemimpinan Paku Buwono X. Taman Sriwedari awal mulanya dibangun sebagai pengembangan dari Desa Talawangi, Kadipolo. Taman Sriwedari disebut sebagai Bon Rojo atau Kebon Raja, yang dibangun pada 28 mulud dal 1831 (windhu sancoyo, wuku wukir, mongso koso atau 17 Juli 1901 M dengan sengkalan candra janmo guno ngesti gusti) $[8,9]$. Kebijakan pengembangan setelah era kemerdekaan dipengaruhi oleh pengelolaan oleh Pemerintah Kota Surakarta. Secara ekonomi dan sosial, dinamika perkembangan ekonomi kota juga mempengaruhi minat masyarakat untuk mengunjungi taman. Sejalan dengan pendapat Kostof, perkembangan Taman Sriwedari tidak lepas dari berbagai fenomena yang terjadi pada tingkat kota.

Menurut UU No 11 Tahun 2010 tentang Cagar Budaya [10], kawasan cagar budaya adalah satuan ruang geografis yang memiliki dua situs cagar budaya atau lebih yang letaknya berdekatan dan/atau memiliki ciri tata ruang yang khas. Berdasarkan UU tersebut, dapat dikatakan bahwa Taman Sriwedari merupakan kawasan cagar budaya karena di dalamnya 
terdapat beberapa bangunan yang berstatus cagar budaya seperti Museum Radya Pustaka, Rumah Sakit Jiwa Mangunjayan, dan Stadion Sriwedari. Kawasan cagar budaya yang biasanya terdapat di area dengan populasi tinggi seringkali menemui fenomena beradunya keinginan modernisasi, inovasi, dan perkembangan yang bertolak belakang dengan pelestarian sejarah dan cagar budaya [11]. Hingga kini, Kawasan Taman Sriwedari telah mengalami banyak perubahan secara spasial maupun aspasial. Modernisasi dan kebijakan pembangunan kota semakin menghilangkan ruh Taman Sriwedari sebagai Taman Raja yang memiliki nilai sejarah dan budaya masyarakat Kota Surakarta. Salah satu pengembangan yang sedang berlangsung adalah pembangunan Masjid Raya Taman Sriwedari yang ditempatkan di lahan eks salah satu taman hiburan di area internal sebelah timur Stadion Sriwedari. Untuk mencegah perubahan yang lebih besar dan jauh dari konsep awal Kebun Raja, penelitian ini memberikan gambaran perkembangan Taman Sriwedari untuk dapat menjadi masukan bagi pemangku kepentingan dalam melakukan revitalisasi taman terkait bagaimana ruang publik digunakan sejak dahulu sampai mencapai puncak kejayaannya sebagai ruang publik. Dalam lingkup yang lebih luas diharapkan studi ini dapat memberikan tambahan pengetahuan mengenai pengelolaan ruang publik di pusat kota yang memiliki signifikansi sejarah dan budaya.

Kebaruan ditemukenali dari perbedaan fokus penelitian dari penelitian-penelitian yang sudah ada sebelumnya. Arifianto [12] dan Iswari [13] memiliki fokus penelitian tentang redesain dan penilaian efektivitas Taman Sriwedari sebagai ruang publik, tetapi tidak membahas mengenai eksistensi ditinjau dari perkembangan peran dan fungsi ruang, serta interaksi komponen di dalamnya. Terkait dengan penelitian yang berfokus pada eksistensi ruang publik, Mulyanto [14] dan Andriani [15] melakukan kajian terhadap eksistensi ruang publik di Kota Surakarta, akan tetapi memiliki perbedaan jenis dan karakter ruang publik yang menjadi lokus penelitian, sehingga permodelan pemahaman eksistensi ruang yang diteliti juga berbeda. Dalam upaya memberikan kebaruan dalam penelitian terkait eksistensi ruang publik, penelitian ini bertujuan untuk menemukenali perkembangan Taman Sriwedari, ditinjau dari perubahan penggunaan ruang, fenomena yang melatarbelakangi, dan pengaruhnya terhadap aktivitas.

\section{Metode}

Penelitian ini merupakan jenis penelitian kualitatif dengan pendekatan naratif, yaitu dengan penjabaran secara kronologis terhadap penggunaan ruang yang dituliskan melalui metode penulisan sejarah. Penulisan kronologi perubahan penggunaan ruang dijabarkan ke dalam 3 periode, yakni periode 1901-1945, periode 1946-1984, dan periode 1984-saat ini. Kemudian analisis juga dilakukan menggunakan instrumen georeferencing. Teknik analisis data menggunakan metode sejarah dan pemetaan secara spasial. Deskripsi dilakukan dengan membagi perubahan fungsi lahan dan bangunan kawasan menjadi beberapa periode untuk memudahkan dalam mengidentifikasi perubahan berdasarkan fenomena tertentu. Analisis spasial dilakukan untuk memperoleh gambaran secara spasial (visual) yang diinterpretasi dari peta dan/atau dibantu dengan data-data deskriptif. Secara umum, batasan kawasan penelitian didasarkan pada batasan Taman Sriwedari pada awal dibangun yang tercantum dalam beberapa literatur sejarah seperti pada Gambar 1. 


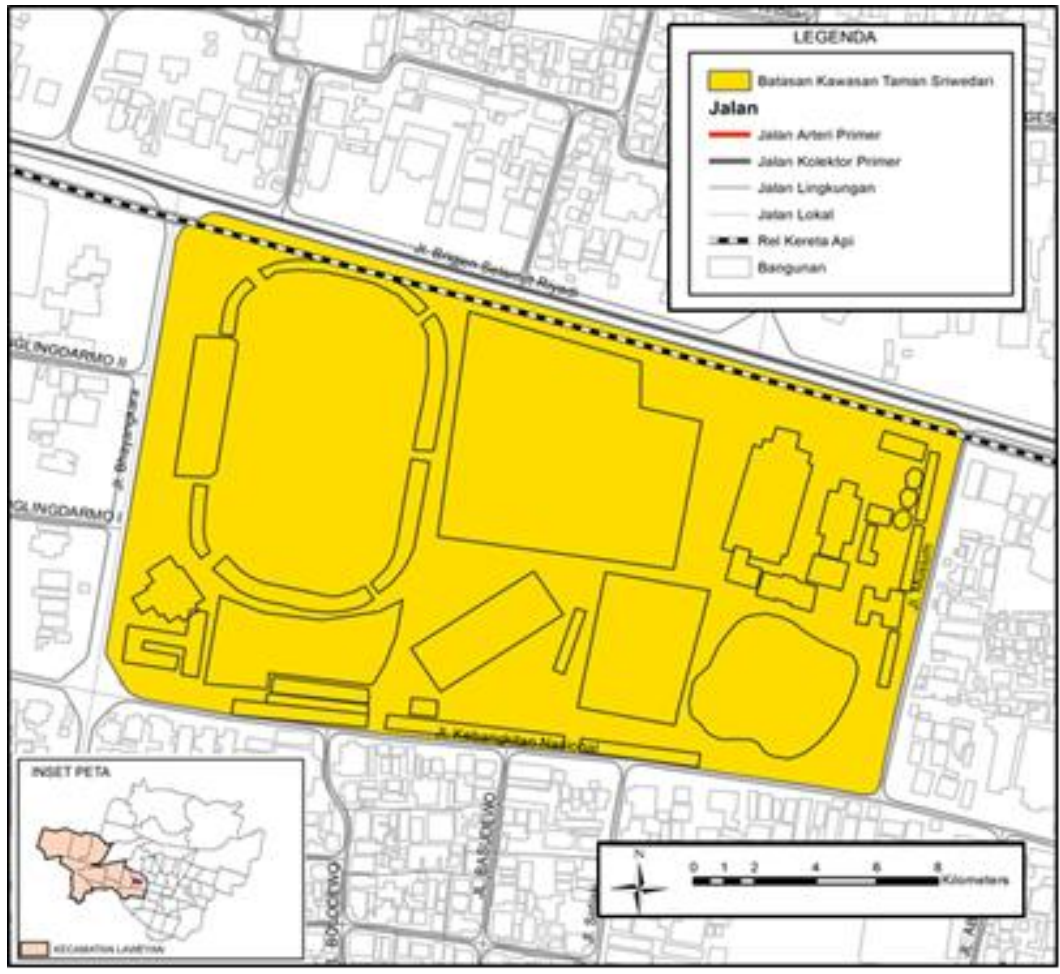

Gambar 1. Peta batasan Kawasan Taman Sriwedari $[8,9,16]$.

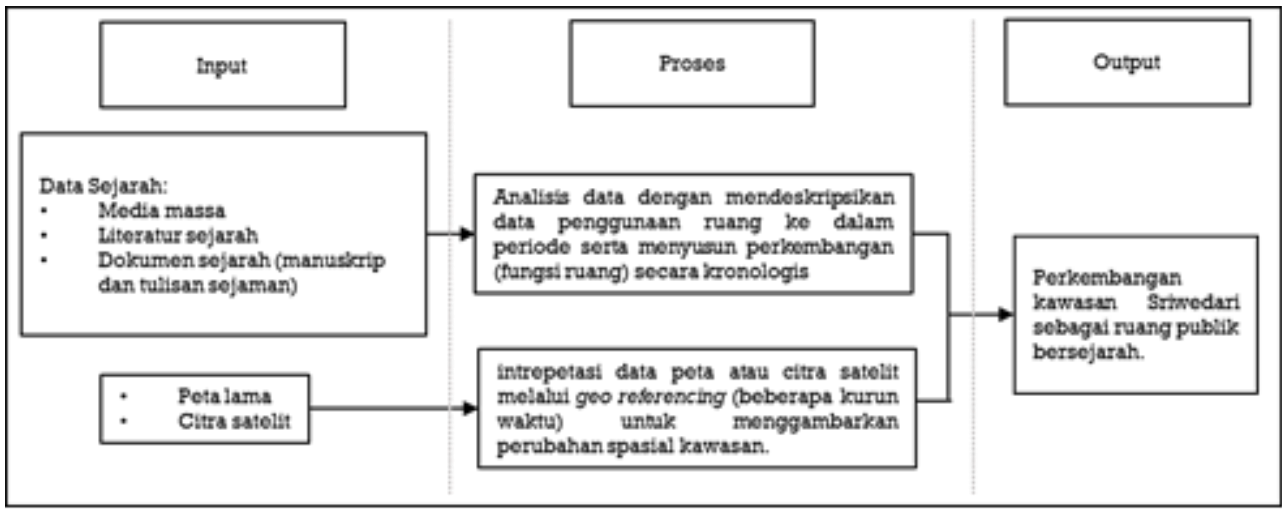

Gambar 2. Kerangka analisis penelitian.

Metode pengumpulan data dilakukan melalui survey data primer dan survey data sekunder. Survey data primer dilakukan melalui observasi dan wawancara. Observasi dilakukan untuk mengidentifikasi kondisi eksisting kawasan, sedangkan wawancara menggunakan teknik snowball untuk mengetahui informasi dari ahli maupun pelaku aktivitas. Survey data sekunder dilakukan dengan penelaahan terhadap literatur, antara lain literatur sejarah dan dokumen sejarah seperti media massa, manuskrip, majalah, peta lama atau tulisan sejaman. Untuk mengetahui perubahan spasial, penelitian menggunakan data-data terkait perubahan fungsi lahan, antara lain menggunakan peta lama, citra satelit, dan penggunaan lahan. Kerangka analisis dalam penelitian ini dijelaskan pada Gambar 2. 


\section{Hasil penelitian dan pembahasan}

\subsection{Sejarah Kawasan Taman Sriwedari}

Menurut Buwono XII \& Mutholín [9] Sriwedari disebut dengan Kebon Raja atau masyarakat biasa menyebutnya dengan Bonrojo. Pada kondisi aslinya, Sriwedari merupakan taman kota yang dibangun diatas tanah di daerah bernama Kadipolo. Taman Sriwedari dibangun pada tahun 1901, 28 mulud dal 1831 (windhu sancoyo, wuku wukir, mongso koso atau 17 Juli 1901 $\mathrm{M}$ dengan sengkalan candra janmo guno ngesti gusti) di masa pemerintahan Paku Buwono $\mathrm{X}$ (1893-1939). Pembangunan taman ini dimaksudkan sebagai taman tempat rekreasi dan peristirahatan keluarga kerajaan. Berbeda dengan ruang terbuka alun-alun yang biasanya terdapat di dalam lingkungan kerajaan, Taman Sriwedari merupakan taman raja yang terdapat di luar keraton.

Pada saat perpindahan Istana Surakarta pada tahun 1746, Sala atau Surakarta masih memiliki banyak lahan kosong. Namun, pada zaman kekuasaan Paku Buwono X, Sala sudah menjadi tempat yang cukup ramai dan pada masa itu pun dikenal sebagai masa kejayaan Kasunanan Surakarta Hadiningrat. Kejayaan tersebut tidak terlepas dari jasa patih pada masa pemerintahan Paku Buwono X, yaitu Kanjeng Raden Adipati Sosrodiningrat IV yang terkenal kemampuannya dalam mengelola kerajaan. Patih Sosrodiningrat IV memberikan gagasan untuk membangun sebuah taman, kemudian dipilih sebidang tanah di Kadipala [8]. Dengan memerintahkan abdi dalem kerajaan, dibangunlah sebidang tanah di Desa Talawangi yang masih belum dimanfaatkan untuk dijadikan sebuah taman, yaitu Taman Sriwedari [16]. Pada tanggal 5 Desember 1887, tanah tersebut dibeli dari orang Belanda, Johannes Busselaar, yang juga menjual bidang tanah yang kini menjadi Museum Radya Pustaka. Luas taman pada kondisi aslinya melingkupi $10 \mathrm{Ha}$ di selatan Groote Postweg, jalan pos utama bernama Poerwosari Weg yang kini dikenal dengan Jalan Slamet Riyadi. Di sebelah timurnya merupakan Jalan Museum, dan sebelah baratnya merupakan lahan kosong yang pada beberapa masa kemudian menjadi Stadion Sriwedari [9].

Nama Taman Sriwedari berasal dari cerita pewayangan Sumantri yang artinya taman kahyangan atau taman surga. Taman Sriwedari diresmikan pada tahun Dal, 1831 atau tahun 1899 Masehi dengan sengkalan luwih katon esthining wong [16]. Suasana Taman Sriwedari digambarkan dalam sebuah tulisan Yasahardjana pada tahun 1926 berjudul Babad Taman Sriwedari. Visualisasi tersebut juga didukung oleh data peta lama Surakarta tahun 1927 pada Gambar 3. 


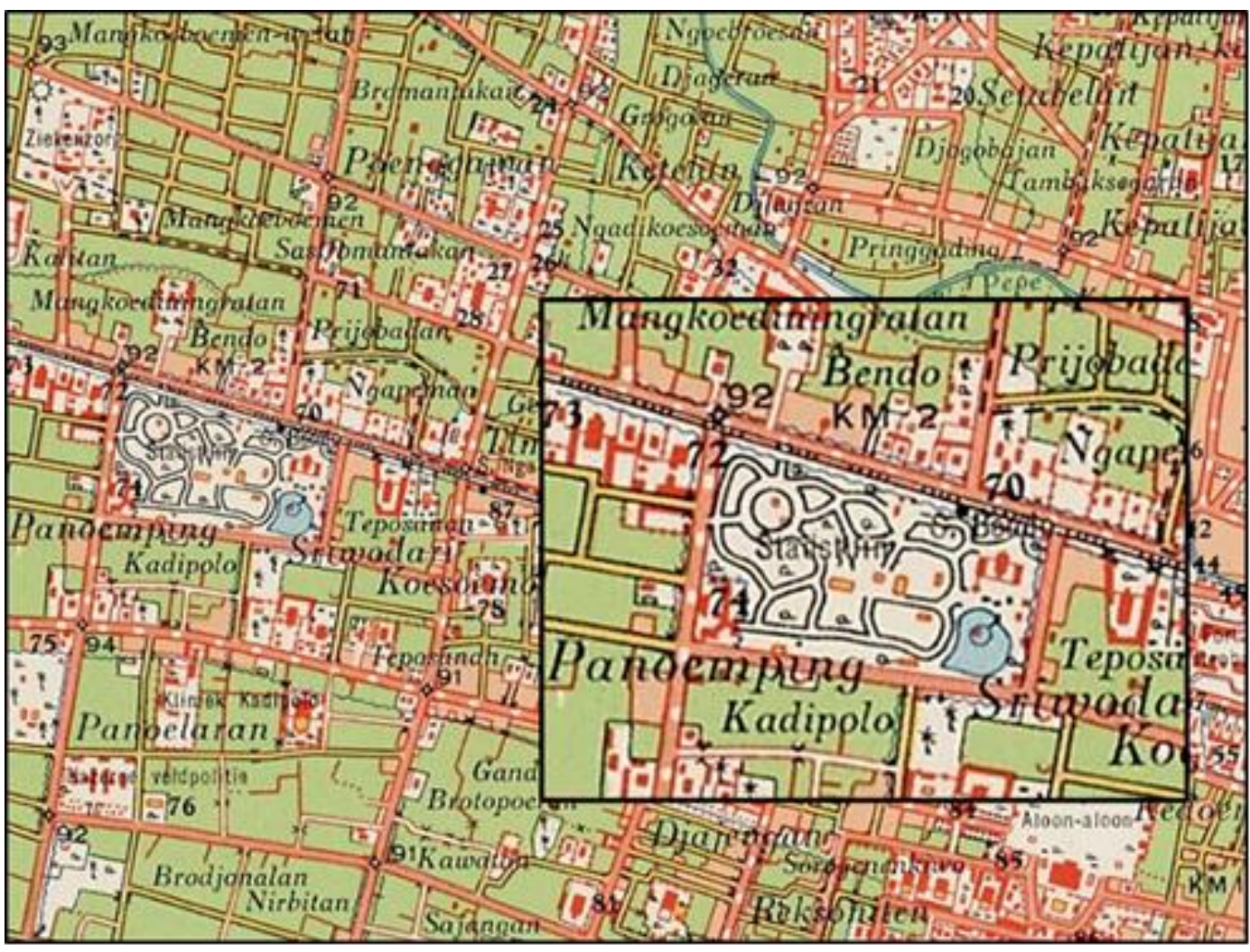

Gambar 3. Kawasan Taman Sriwedari pada peta Kota Surakarta tahun 1927 [17].

Peta tersebut menunjukkan sebagian besar lahan (hampir $2 / 3$ bagian lahan) pada awal pembangunan merupakan lahan terbuka yang memiliki jalan-jalan bercabang. Kelengkapan taman kota atau fasilitas yang dimiliki Taman Sriwedari juga terlihat dari persil bangunan. Fasilitas tersebut antara lain: Museum Radya Pustaka, Rumah Sakit Jiwa Mangunjayan, dan Segaran. Sedangkan suasana di Taman Sriwedari pada awal dibangun sebagai taman kota secara lebih rinci digambarkan dalam Babad Taman Sriwedari. Bangunan depan Sriwedari berbentuk persegi empat, dikelilingi pagar tajam dengan kawat berduri. Didalamnya juga dilengkapi dengan flora berupa vegetasi pohon-pohon bertajuk serta fauna berupa hewanhewan koleksi keraton.

Bentuk dari Taman Sriwedari di awal pembangunannya memiliki konsep yang tidak lepas dari fungsi hiburan dan relaksasi. Salah satu daya tarik taman Sriwedari pada saat itu adalah kebun binatang yang dibangun pada tahun 1905 [18]. Satwa-satwa kebun binatang tersebut merupakan koleksi keraton, baik dari dalam maupun dari luar lingkungan keraton. Pada sketsa Taman Sriwedari menurut Babad Taman Sriwedari, kebun binatang tersebut menempati lahan di sebelah selatan (ke arah barat) dan di bagian sisi timur dari taman. Paku Buwono $X$ memelihara beberapa jenis hewan yang diantaranya juga merupakan hewan hasil buruan, seperti rusa, gajah, dan buaya.

Daya tarik lainnya adalah kolam yang juga berada di bagian timur taman, kolam tersebut diberi nama Segaran yang diambil dari bahasa jawa dengan arti lautan. Di bagian tengah kolam 
terdapat bangunan Panti Pangaksi, yaitu rumah kupel yang dindingnya melingkar dengan kaca aneka warna. Pada bagian bawah Panti Pangaksi dibuat bentuk bangunan mirip goa, yang kemudian disebut sebagai Gua Suara. Ruangan ini digunakan untuk menyimpan perangkat gamelan keraton, yakni Gamelan Satiswaran. Pada saat ada pertemuan, gamelan tersebut akan dibunyikan [16].

\subsection{Perkembangan ruang publik}

Dalam mendeskripsikan perkembangan Kawasan Taman Sriwedari, pembahasan dibagi ke dalam tiga periode. Periode awal adalah tahun 1901-1945, kemudian periode kedua tahun 1946-1985, selepas itu periode ketiga yaitu tahun 1986-saat ini. Pembagian tersebut dimaksudkan untuk mempermudah dalam menggambarkan perubahan Taman Sriwedari sesuai dengan beberapa fenomena yang terjadi.

3.2.1. Periode I (1901-1945). Periode awal perkembangan Taman Sriwedari sangat dipengaruhi oleh pemerintahan Kasunanan Surakarta Hadiningrat, sehingga tidak jauh dari konsep maupun filosofi dalam kebudayaan Jawa. Taman Sriwedari dikatakan sebagai Kebon Rojo karena masyarakat mengenal taman ini dibuat sebagai tempat peristirahatan keluarga raja. Meskipun demikian, Paku Buwono X juga memperuntukkan taman ini sebagai taman hiburan yang dapat diakses oleh seluruh kalangan masyarakat. Peta periode I dapat dilihat dalam Gambar 4, Taman Sriwedari merupakan taman kota sekaligus taman hiburan yang cukup lengkap pada masanya. Sedangkan fungsi ruang Taman Sriwedari dapat dilihat pada Tabel 1.

Tabel 1. Fungsi ruang pada periode 1901-1945 [8,9,16,18].

\begin{tabular}{|c|c|c|c|}
\hline Tempat & Fungsi & Deskripsi & Tahun Berdiri \\
\hline $\begin{array}{l}\text { Taman (ruang } \\
\text { terbuka hijau) }\end{array}$ & $\begin{array}{l}\text { Wisata taman kota dan } \\
\text { sarana relaksasi }\end{array}$ & $\begin{array}{l}\text { Bangunan depan berbentuk persegi } \\
\text { empat dikelilingi pagar tajam dengan } \\
\text { kawat berduri. Jalanan di dalamnya } \\
\text { dibuat berliku-liku. Di pinggir jalannya } \\
\text { ditanami pohon cemara, palem, } \\
\text { trembesi, dan kenari. }\end{array}$ & $\begin{array}{l}1901 \\
1933 \text { dibangun } \\
\text { Sarana Olahraga } \\
\text { Stadion Sriwedari } \\
\text { di sebelah barat } \\
\text { taman. }\end{array}$ \\
\hline $\begin{array}{l}\text { Bangunan rumah } \\
\text { di tengah taman }\end{array}$ & $\begin{array}{l}\text { Tempat istirahat dan } \\
\text { berjualan }\end{array}$ & $\begin{array}{l}\text { Rumah yang menghadap ke segala arah } \\
\text { dengan ukiran dan sambungan kayu } \\
\text { tanpa dipaku. Rumah tersebut dibuat } \\
\text { sedikit lebih tinggi untuk dapat melihat } \\
\text { ke sekeliling taman. Di sekeliling rumah } \\
\text { tersebut ditanami bunga warna warni } \\
\text { sesuai dengan jenisnya. }\end{array}$ & 1901 \\
\hline $\begin{array}{l}\text { Telaga dengan } \\
\text { bangunan (Panti } \\
\text { Pangaksi atau } \\
\text { rumah kupel) } \\
\text { ditengahnya } \\
\text { (Segaran) }\end{array}$ & $\begin{array}{l}\text { Tempat istirahat raja } \\
\text { sambil melihat taman } \\
\text { Tempat menyimpan } \\
\text { dan pertunjukkan } \\
\text { gamelan } \\
\text { Tempat menyimpan } \\
\text { keris raja } \\
\text { Tempat pertunjukkan } \\
\text { musik }\end{array}$ & $\begin{array}{l}\text { Di sebelah timur terdapat telaga yang } \\
\text { ditanami teratai, kayu apu, dan hewan } \\
\text { piaraan seperti belibis, bangau, angsa } \\
\text { besar, dan berpagar tembok di sekeliling } \\
\text { kolam. Di tengah telaga terdapat } \\
\text { gundukan yang dibuat panggung } \\
\text { berbentuk persegi enam yang } \\
\text { dinamakan Panti Pangaksi. Di sebelah } \\
\text { tenggara terdapat telaga dan kandang }\end{array}$ & 1901 \\
\hline
\end{tabular}




\begin{tabular}{|c|c|c|c|}
\hline Tempat & Fungsi & Deskripsi & Tahun Berdiri \\
\hline Kebun binatang & $\begin{array}{l}\text { Tempat memelihara } \\
\text { satwa dan tanaman air } \\
\text { Sarana relaksasi } \\
\text { Tempat pertunjukkan } \\
\text { seni } \\
\text { Kandang satwa koleksi } \\
\text { Taman Sriwedari dan } \\
\text { wisata edukasi satwa }\end{array}$ & $\begin{array}{l}\text { gajah (di telaga tersebut terdapat buaya, } \\
\text { bulus, dan kura-kura). Di dekat Panti } \\
\text { Pangaksi terdapat gua bernama Gua } \\
\text { Suara. } \\
\text { Di sebelah selatan terdapat kandang } \\
\text { babi, sapi, banteng. Di tenggara telaga } \\
\text { terdapat gajah. Sebelah utaranya } \\
\text { terdapat kandang ayam mas, ayam } \\
\text { tembagi, kandang macan (macan } \\
\text { gembong, macan kumbang), kera, } \\
\text { monyet, landak, anjing, burung warna- } \\
\text { warni, kambing, bebek, burung kuntul, } \\
\text { dan jenis burung lainnya. Di sebelah } \\
\text { barat terdapat kandang ular. }\end{array}$ & 1905 \\
\hline $\begin{array}{l}\text { Panggung- } \\
\text { panggung } \\
\text { pertunjukkan }\end{array}$ & $\begin{array}{l}\text { Sarana Pertunjukkan } \\
\text { layar tancap dan } \\
\text { wayang orang }\end{array}$ & $\begin{array}{l}\text { Pada malam Jumat dan malam Minggu } \\
\text { terdapat pertunjukkan layar tancap dan } \\
\text { wayang orang. }\end{array}$ & $\begin{array}{l}1901 \text { Panggung } \\
\text { layar tancap dan } \\
\text { wayang orang } \\
1914 \text { Gedung } \\
\text { Sriwedari } \\
\text { Bioscoop } \\
\text { 1928-1930 } \\
\text { (Gedung Wayang } \\
\text { Orang) }\end{array}$ \\
\hline $\begin{array}{l}\text { Museum Radya } \\
\text { Pustaka }\end{array}$ & $\begin{array}{l}\text { Wisata edukasi literatur } \\
\text { Jawa, koleksi benda } \\
\text { bersejarah, serta } \\
\text { tempat pelatihan seni } \\
\text { gamelan dan wayang. }\end{array}$ & $\begin{array}{lrr}\text { Sebuah museum benda } & \text { purbakala } \\
\text { sekaligus berfungsi } & \text { sebagai } \\
\text { perpustakaan literatur Jawa } & \end{array}$ & 1913 \\
\hline $\begin{array}{l}\text { Rumah Sakit } \\
\text { Mangunjayan }\end{array}$ & Sarana kesehatan & $\begin{array}{l}\text { Rumah sakit jiwa yang terletak di sisi } \\
\text { barat daya Taman Sriwedari }\end{array}$ & 1918 \\
\hline Stadion Sriwedari & Sarana olahraga & $\begin{array}{l}\text { Merupakan stadion terbuka di sisi barat } \\
\text { taman }\end{array}$ & 1933 \\
\hline
\end{tabular}

Taman Sriwedari juga dikenal sebagai tempat pelaksanaan Maleman, sebuah festival kota yang berawal dari tujuan religius. Maleman merupakan festival yang dilaksanakan setiap bulan Ramadhan untuk memfasilitasi masyarakat muslim yang menunggu malam lailatul qadar. Pada malam ke-21, dilaksanakan sebuah tradisi Malam Selikuran di area Segaran. Tradisi tersebut merupakan sebuah simbol bagi perayaan malam lailatul qadar. Sejak awal, disamping perayaan yang bersifat khidmat berhubungan dengan konsep religi, Maleman Sriwedari juga diisi oleh berbagai aktivitas perdagangan serta atraksi-atraksi seni tradisional. Dalam sebuah media massa Belanda, Soerabaijasch Handelsblad 18 Januari 1930, Maleman digambarkan sebagai sebuah festival besar yang menampilkan pameran seni, permainan tradisional, dan beberapa kompetisi olahraga. 


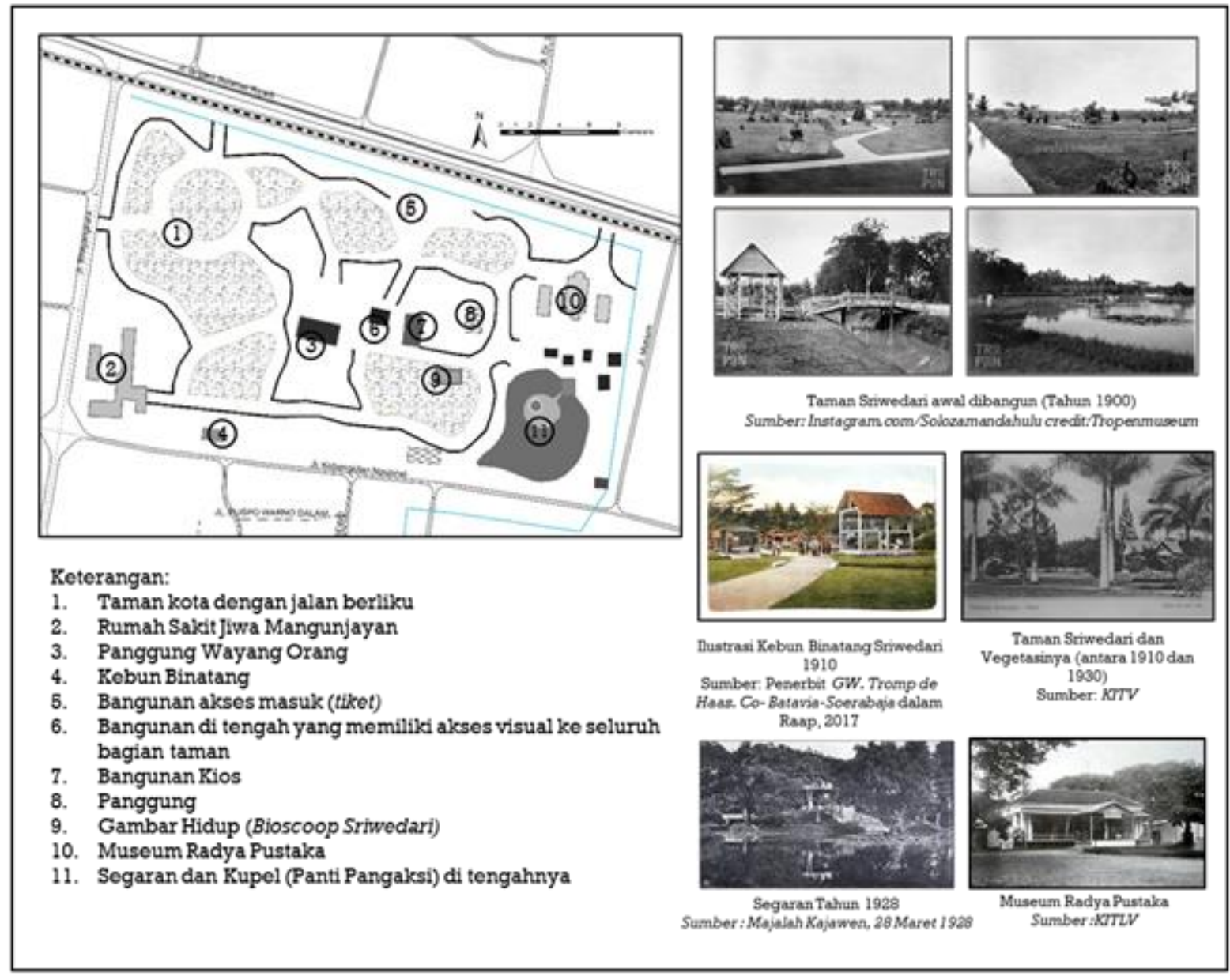

Gambar 4. Kolase gambaran Taman Sriwedari pada periode I (sebelum stadion dibangun) $[8,9,16,17,19,20]$.

Selama pemerintahan Kasunanan Surakarta Hadiningrat, Kawasan Sriwedari pernah berfungsi sebagai ruang politik, yakni terjalinnya komunikasi politik antara raja dengan rakyatnya, baik dalam menyampaikan keinginan, kebijakan, maupun menyampaikan informasi adanya upacara adat. Komunikasi tersebut membutuhkan ruang-ruang umum atau fasilitas sosial, oleh karena itu Kawasan Sriwedari dipilih karena statusnya sebagai Kebun Raja dan fasilitas publik. Kawasan Sriwedari juga berperan sebagai ruang penyampaian komunikasi politik pada masa Kasunanan.

...Kalau untuk Sriwedari itu ada dikaitkan di dalam Keraton itu ada yang namanya Manunggaling kawula gusti, itu cara bagaimana Raja berkomunikasi kepada masyarakat, yang paling ideal adalah melalui tempat publik, atau ruang terbuka, atau fasilitas umum, termasuk seperti Sriwedari itu. ...Sriwedari sebagai tempat publik itu seperti apa. kehadiran Raja dalam waktu-waktu tertentu, nah kalau dalam politik itu disebut dengan komunikasi politik, dimana Raja melakukan suatu komunikasi dengan kawula....[21] 
Kemudian, dikatakan bahwa komunikasi tersebut juga disampaikan melalui media wayang orang [21].

....Jadi sosialisasi politik terkait dengan bagaimana Raja menginginkan atau punya kebijakan tertentu, disosialisasikan kepada masyarakat misalnya punya program atau akan ada acara apa, nah di dalam wayang diceritakan , ajaran-ajarannya...

Pada masa-masa pergerakan, Taman Sriwedari digunakan sebagai tempat bagi rapat-rapat organisasi politik, salah satunya Sarekat Islam. Pertemuan atau kongres Sarekat Islam dilaksanakan pada 23 Mei 1914 [22], kemudian pada tahun 1915 kembali mengadakan pertemuan di Sriwedari [23]. Dalam harian De Indische Courant, 23 Mei 1933 [24] diceritakan bahwa Stadion Sriwedari menjadi lokasi bagi pawai dan pertandingan sepak bola dalam rangka memperingati 25 tahun berdirinya organisasi Budi Utomo. Dalam harian tersebut juga dikomentari sebagai kepandaian Budi Utomo dalam menunjukkan eksistensinya sebagai organisasi di tengah masyarakat. Fungsi politik hanya terjadi pada periode I disebabkan oleh perubahan sistem pemerintahan setelah kemerdekaan pada periode II sehingga tidak memungkinkan lagi adanya kepentingan raja atau organisasi politik dalam lingkup kota yang membutuhkan ruang demokratis.

Salah satu daya tarik yang lain adalah Wayang Orang Sriwedari. Berdasarkan beberapa narasumber dalam Hersapandi [25], wayang orang kemungkinan sudah mulai berpentas sekitar tahun 1910 hingga 1912. Menurut wawancara dengan Drs. Susanto, ahli sejarah, Wayang Orang Sriwedari selain sebuah tontonan juga berperan sebagai tuntunan bagi masyarakat. Pada saat menonton wayang orang, seseorang seperti berkaca pada dirinya sendiri.

"Nilai orang jawa pada saat itu masih berkaitan dengan nilai wayang, sopan santun, pemerintahan, perilaku masyarakat bagaimana itu harus sesuai wayang. Maka nonton wayang sebetulnya adalah ibarat menonton dirinya sendiri, atau melihat 'perilaku saya masih pantas atau tidak ya?"

Sampai menjelang kemerdekaan Indonesia, tekanan-tekanan politik mempengaruhi kehidupan sosial dan psikologis masyarakat kota. Sehingga dalam konteks penggunaan ruang publik, minat masyarakat untuk berkunjung ke Taman Sriwedari juga dipengaruhi oleh kondisi keamanan kota pada masa itu.

3.2.2. Periode II (1946-1948). Perubahan sistem pemerintahan Surakarta dari kekuasaan keraton ke kekuasaan Republik Indonesia turut mempengaruhi pengelolaan beberapa asetaset kota. Kemerdekaan Indonesia membawa dampak pada perubahan politik, sosial, ekonomi, dan psikologis. Ricklefs dalam Hersapandi [25] menerangkan bahwa atas desakan para kaum radikal dan Soedirman, hak-hak istimewa para raja Surakarta di luar tembok istana secara resmi dihapus oleh Pemerintah Republik Indonesia pada tanggal 1 Juni 1946. Salah satu aset keraton, Taman Sriwedari kemudian berpindah pengelolaan ke Pemerintah Daerah Kotamadya Surakarta, yaitu oleh Bidang Jawatan Penghasilan Daerah. 
Tahun 1945-1946 merupakan saat-saat penting bagi keberlanjutan pengembangan Taman Sriwedari karena pindahnya manajemen pengelolaan ruang publik. Pada periode ke II, secara fisik Taman Sriwedari tidak terlalu banyak mengalami perubahan fisik yang signifikan karena aktivitas didalamnya masih dilaksanakan dan dipertahankan seperti sebelumnya. Wayang Orang Sriwedari dan Maleman Sriwedari misalnya, merupakan dua aktivitas yang masih bertahan dan ikut serta membesarkan nama Sriwedari. Pada kasus Wayang Orang Sriwedari, karena tingginya animo masyarakat, pemerintah kota meningkatkan sarana dan prasarana yaitu Gedung Wayang Orang baru pada tahun 1950-1951 [25]. Sedangkan Maleman Sriwedari masih menjadi sebuah festival besar yang menghadirkan berbagai pertunjukkan seni dan budaya, tidak hanya dari dalam kota melainkan kesenian dari luar Kota Surakarta juga ikut tampil dalam perayaan. Pada periode ini dapat dikatakan sebagai masa keemasan Taman Sriwedari dikenal mulai dari pelaksanaan PON I di Stadion Sriwedari pada tahun 1948 [26]. Kemudian acara tahunan Maleman setiap bulan Ramadan dan pertunjukkan wayang orang yang masih diminati masyarakat. Sampai pada akhir periode II, yaitu tahun 1983, Taman Sriwedari mulai mengalami penurunan kualitas manajemen pada sisi lainnya, yaitu pengelolaan kebun binatang. Bersamaan dengan rencana perluasan Stadion Sriwedari, yaitu untuk lahan parkir, sebagian besar satwa penghuni Kebun Binatang Sriwedari akhirnya dipindahkan ke Taman Satwa Taru Jurug [27].

Munculnya perdagangan di area taman Sriwedari selain berkaitan dengan posisinya sebagai sarana pariwisata kota, juga didorong oleh beberapa ritual atau tradisi yang berkembang di dalamnya. Seperti yang terjadi di Kampung Luar Batang, Jakarta, dalam penelitian Puspitasari, Djunaedi, \& Sudaryono [28] yaitu perubahan spasial (dengan bentuk cyclical changes). Perubahan tersebut terkait dengan perkembangan aktivitas komersial bersiklus yang didorong oleh tradisi religius yaitu ziarah yang berlangsung secara rutin di lingkungan kampung. Dalam konteks Taman Sriwedari, ruang kawasan erat dengan pelaksanaan Maleman yang merupakan tradisi religius pada bulan Ramadhan, yang turut mendorong munculnya sebuah lingkungan komersial yang lebih besar, seperti bazar (barang dan kuliner) dan pameran barang-barang produksi. Berkaitan dengan perubahan ruang lainnya periode II dapat dilihat pada Tabel 2 dan Gambar 5.

Tabel 2. Perubahan ruang pada periode II $[25,27,29]$.

\begin{tabular}{|c|c|c|}
\hline Perubahan & Keterangan & Tahun \\
\hline $\begin{array}{l}\text { Pembangunan Gedung Wayang } \\
\text { Orang baru }\end{array}$ & $\begin{array}{l}\text { Dibangun di sebelah selatan } \\
\text { gedung lama }\end{array}$ & 1950-1951 \\
\hline $\begin{array}{l}\text { Pembangunan Gedung Bioskop } \\
\text { Solo Theater }\end{array}$ & $\begin{array}{l}\text { Gedung bioskop komersial milik } \\
\text { PT. Sanggar Film Semarang }\end{array}$ & 1972 \\
\hline Kebun binatang & $\begin{array}{l}\text { Berubah menjadi lapangan parkir } \\
\text { stadion }\end{array}$ & 1982 \\
\hline $\begin{array}{l}\text { Terdapat gedung pertunjukkan } \\
\text { Kethoprak }\end{array}$ & $\begin{array}{l}\text { Terdapat gedung kesenian } \\
\text { Kethoprak }\end{array}$ & $\begin{array}{l}\text { Tidak diketahui tahun berdirinya } \\
\text { (diperkirakan setelah 1954, } \\
\text { tahun lahir Kelompok Srimulat) }\end{array}$ \\
\hline $\begin{array}{l}\text { Masuknya } \\
\text { komersial }\end{array}$ & $\begin{array}{l}\text { Gedung perkantoran } \\
\text { Pariwisata, Restoran }\end{array}$ & $\begin{array}{c}\text { Tidak diketahui secara pasti. } \\
\text { Tetapi terdapat di Citra Satelit } \\
\text { tahun } 1983\end{array}$ \\
\hline
\end{tabular}




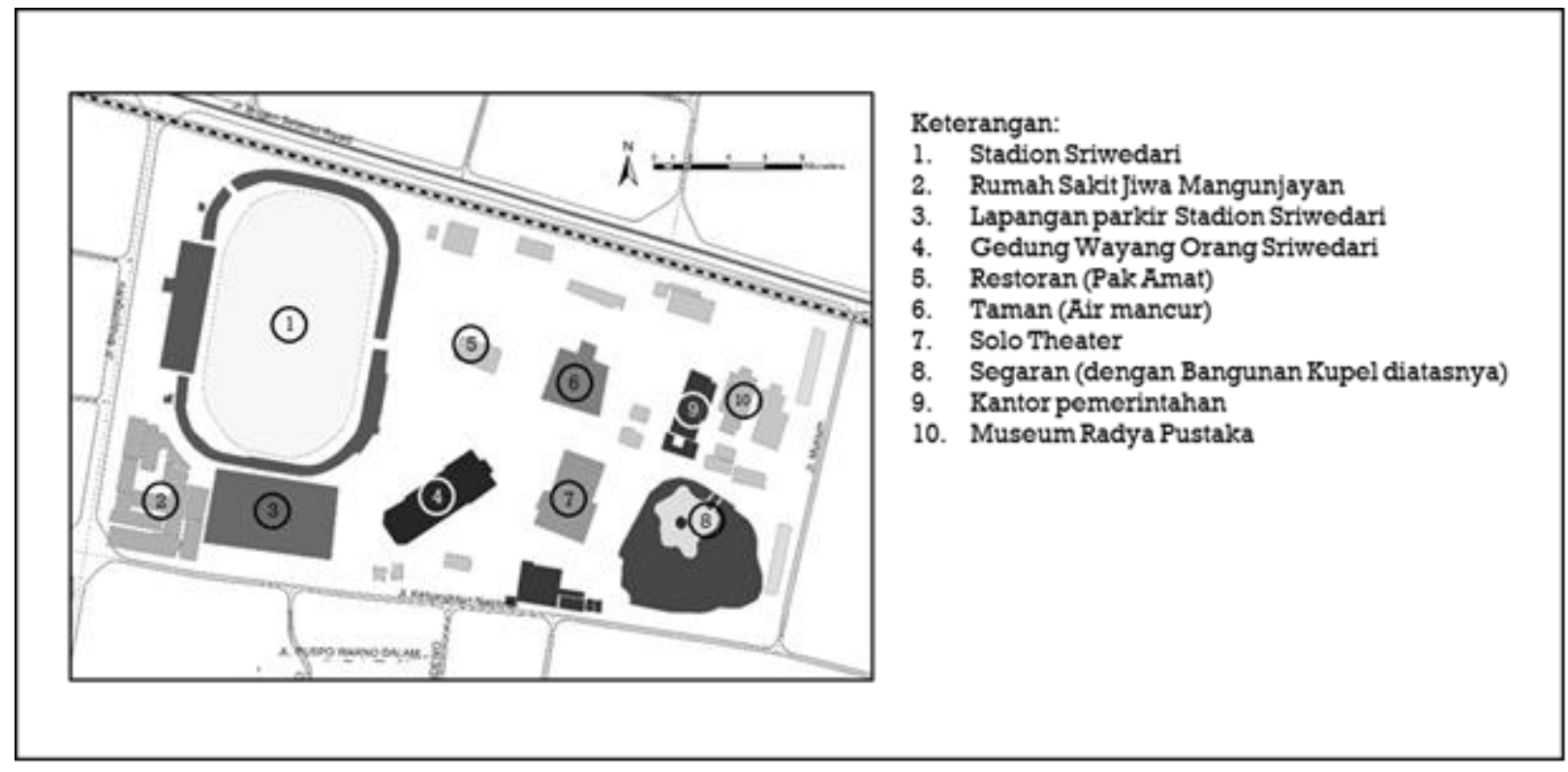

Gambar 5. Peta Taman Sriwedari [30].

3.2.3. Periode III (1984-saat ini). Periode ke- III ini menandai perubahan cukup signifikan yang terjadi pada Taman Sriwedari. Kegiatan yang sifatnya komersial milik swasta mulai memasuki kawasan. Perubahan tersebut sangat dipengaruhi oleh kebijakan Walikota Surakarta periode 1985-1990 mengenai pelibatan pihak ketiga dalam pembangunan. Kebijakan tersebut tertuang dalam Peraturan Daerah Kotamadya Surakarta Nomor 1 tahun 1971 tentang Taman Sriwedari dan Taman Balekambang, tepatnya pada Pasal 6 Ayat 1 yang menyebutkan bahwa walikota atau kepala daerah dapat mengadakan perjanjian dengan pihak lain yang dapat menambah keramaian taman [31]. Perubahan yang terjadi pada periode 3 dapat dilihat di Tabel 3.

Tabel 3. Perubahan pada periode III [25,31,32].

\begin{tabular}{|c|c|c|c|}
\hline \multicolumn{2}{|c|}{ Perubahan Fisik } & \multirow[t]{2}{*}{ Keterangan } & \multirow[t]{2}{*}{ Tahun } \\
\hline Kondisi sebelumnya & Perubahan & & \\
\hline $\begin{array}{l}\text { Lahan kosong sebelah } \\
\text { selatan }\end{array}$ & Solo Theater & Hiburan Bioskop & 1972 \\
\hline $\begin{array}{c}\text { Area Taman Sriwedari } \\
\text { sebelah timur Stadion } \\
\text { Sriwedari }\end{array}$ & Taman Hiburan Rakyat & $\begin{array}{c}\text { Taman hiburan } \\
\text { (permainan anak), } \\
\text { panggung pertunjukkan } \\
\text { musik }\end{array}$ & 1985 \\
\hline Segaran (Kupel) & Rumah Makan Boga & Perdagangan kuliner & 1986 \\
\hline $\begin{array}{l}\text { Area Timur Museum } \\
\text { Radya Pustaka }\end{array}$ & $\begin{array}{c}\text { Dikavling menjadi Pusat } \\
\text { Jajanan Sarwo Asri }\end{array}$ & $\begin{array}{c}\text { disebut dengan Pujasari, } \\
\text { sebagai shelter } \\
\text { pedagang kaki lima }\end{array}$ & 1989 \\
\hline $\begin{array}{c}\text { Area sebelah barat } \\
\text { Museum Radya Pustaka }\end{array}$ & $\begin{array}{l}\text { Gedung pertemuan } \\
\text { Graha Wisata Niaga }\end{array}$ & $\begin{array}{l}\text { Gedung serbaguna (semi } \\
\text { privat) }\end{array}$ & 1992 \\
\hline $\begin{array}{c}\text { Area taman bagian } \\
\text { tengah }\end{array}$ & $\begin{array}{c}\text { Pendapa Mandala } \\
\text { Wisata (joglo) }\end{array}$ & $\begin{array}{c}\text { Gedung serbaguna } \\
\text { (publik) }\end{array}$ & $\begin{array}{c}\text { 1990an (tidak diketahui } \\
\text { tahun tepatnya) }\end{array}$ \\
\hline
\end{tabular}


Pada tahun 1985, Kota Surakarta memformulasikan sebuah konsep pembangunan kota yang disebut dengan Tri Krida Utama, yaitu Surakarta sebagai kota budaya, kota pariwisata, dan kota olahraga [31]. Hal tersebut memunculkan beberapa inisiasi pembangunan di kota yang mengarah pada ketiga konsep tersebut. Namun, pada kasus Taman Sriwedari, kerja sama pihak ketiga menyebabkan perubahan fisik dan aktivitas yang jauh dari upaya mempertahankannya sebagai ruang budaya. Event budaya seperti Maleman, yaitu pada puncak Malam Selikuran tidak lagi dilaksanakan di Segaran, melainkan pindah ke area Joglo Sriwedari. Penggunaan mengarah ke fungsi ruang komersial, hal tersebut dapat dilihat pada Gambar 6. Berdasarkan penelitian Al-Houdalieh \& Sauders [11], perkembangan yang terjadi di bagian kota yang memiliki populasi tinggi biasanya bertentangan dengan pelestarian cagar budaya. Dalam kasus Taman Sriwedari, pengembangan fasilitas komersial dibandingkan dengan mempertahankan fasad asli taman tentunya akan lebih menguntungkan bagi pengusaha, mengingat letak Taman Sriwedari yang ada di pusat kota padat penduduk. Secara aksesibilitas, Taman Sriwedari juga sangat mudah dijangkau oleh penduduk kota. Pada saat itu hiburan masih berpusat di tengah kota. Gambar 6 akan memperlihatkan fungsi bangunan di Taman Sriwedari pada periode III sebelum revitalisasi.

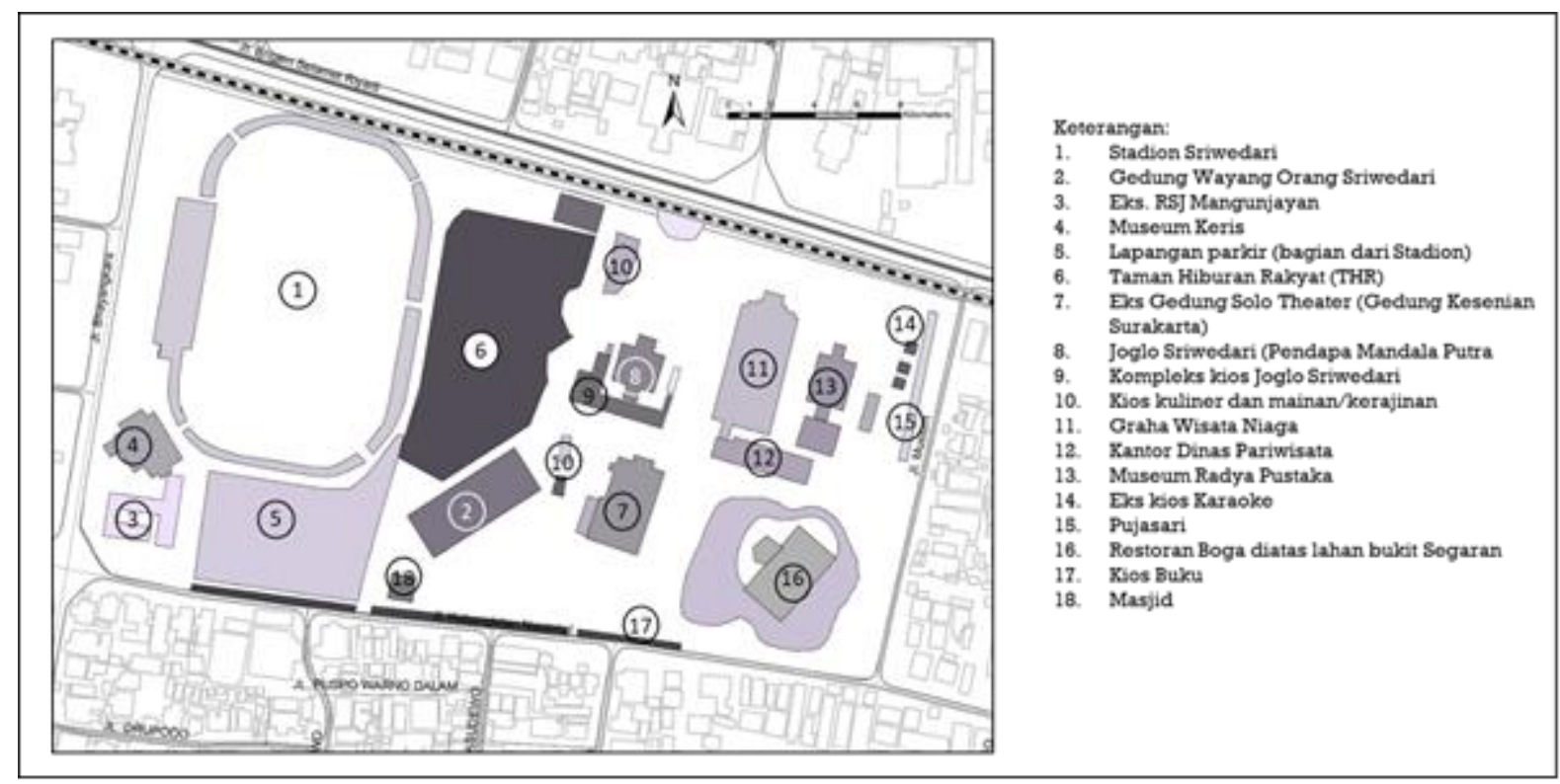

Gambar 6. Peta Taman Sriwedari tahun 2015 [33].

Taman Hiburan Rakyat (1,7 ha) yang mendominasi lahan kawasan merupakan sebuah wahana bermain anak modern. Di dalamnya juga terdapat panggung pertunjukkan musik yang pada akhirnya menjadi ruang ekspresi bagi berbagai komunitas musik dengan berbagai genre. Meskipun bersifat komersial, dengan adanya THR, Taman Sriwedari masih memiliki peran dalam mewadahi berbagai komunitas. Beberapa ruang di Taman Sriwedari lainnya berkembang menjadi sebuah ruang komunitas, salah satunya adalah Joglo Sriwedari yang sering digunakan komunitas tari, seniman lukis, maupun kegiatan masyarakat berbagai kalangan. 
Kegiatan Maleman yang menjadi salah satu daya tarik Taman Sriwedari bertahan sampai dengan tahun 90-an (pertengahan periode III) karena pasar malam tersebut kalah dengan pasar-pasar kaget dan hiburan yang ada di daerah tingkat dua di Surakarta. Selain itu, Maleman juga semakin terbatas dengan dominasi lahan yang dikonsesikan untuk aktivitas swasta (restoran internasional, bioskop, dan taman hiburan) [34].

Periode 1990-an Maleman mulai dilaksanakan tidak rutin, namun Taman Hiburan Rakyat (THR) yang hadir sejak tahun 1985 masih meramaikan Taman Sriwedari [32].

Sekitar tahun 1990, Maleman sudah mulai tidak terlalu ramai... Gambaran Maleman saat sebelum adanya Taman Hiburan Rakyat (THR) sempat diisi oleh hal-hal menarik meskipun seiring berjalannya waktu kemudian aktivitas tersebut mulai ditinggalkan, salah satu alasannya adalah banyaknya bazar-bazar yang sudah mulai berkembang sampai saat ini (di wilayah lain) [35].

Sedangkan Selikuran masih dilakukan sampai akhir periode III, namun dilakukan terbatas di area Joglo Sriwedari yang termasuk bangunan baru setelah berubahnya fungsi Segaran (Panti Pangaksi) menjadi Restoran Boga pada awal periode III.

Taman Sriwedari masih mengalami berbagai tantangan terhadap eksistensinya sebagai ruang publik dengan konsep awal yang diterapkan Paku Buwono X. Sekitar tahun 2000-an, para seniman sering mengadakan upaya untuk membangkitkan kembali Taman Sriwedari yang semakin kurang diminati masyarakat. Salah satunya adalah pertunjukkan seni yang menggunakan setting beberapa bangunan di Taman Sriwedari [36-38]. Bangunan tersebut diantaranya adalah gedung bioskop (yang kemudian sempat digunakan sebagai Gedung Kesenian Surakarta), kemudian disusul oleh Restoran Boga, Taman Hiburan Rakyat (THR), terakhir adalah Joglo Sriwedari. Pada sisi utara Rumah Sakit Mangunjayan digunakan untuk pembangunan Museum Keris pada tahun 2013. Kemudian, pada awal tahun 2019 pemerintah kota memulai untuk melakukan implementasi pembangunan fungsi baru (Gambar 7), yaitu pembangunan Masjid Raya Taman Sriwedari di area eks Taman Hiburan Rakyat. 


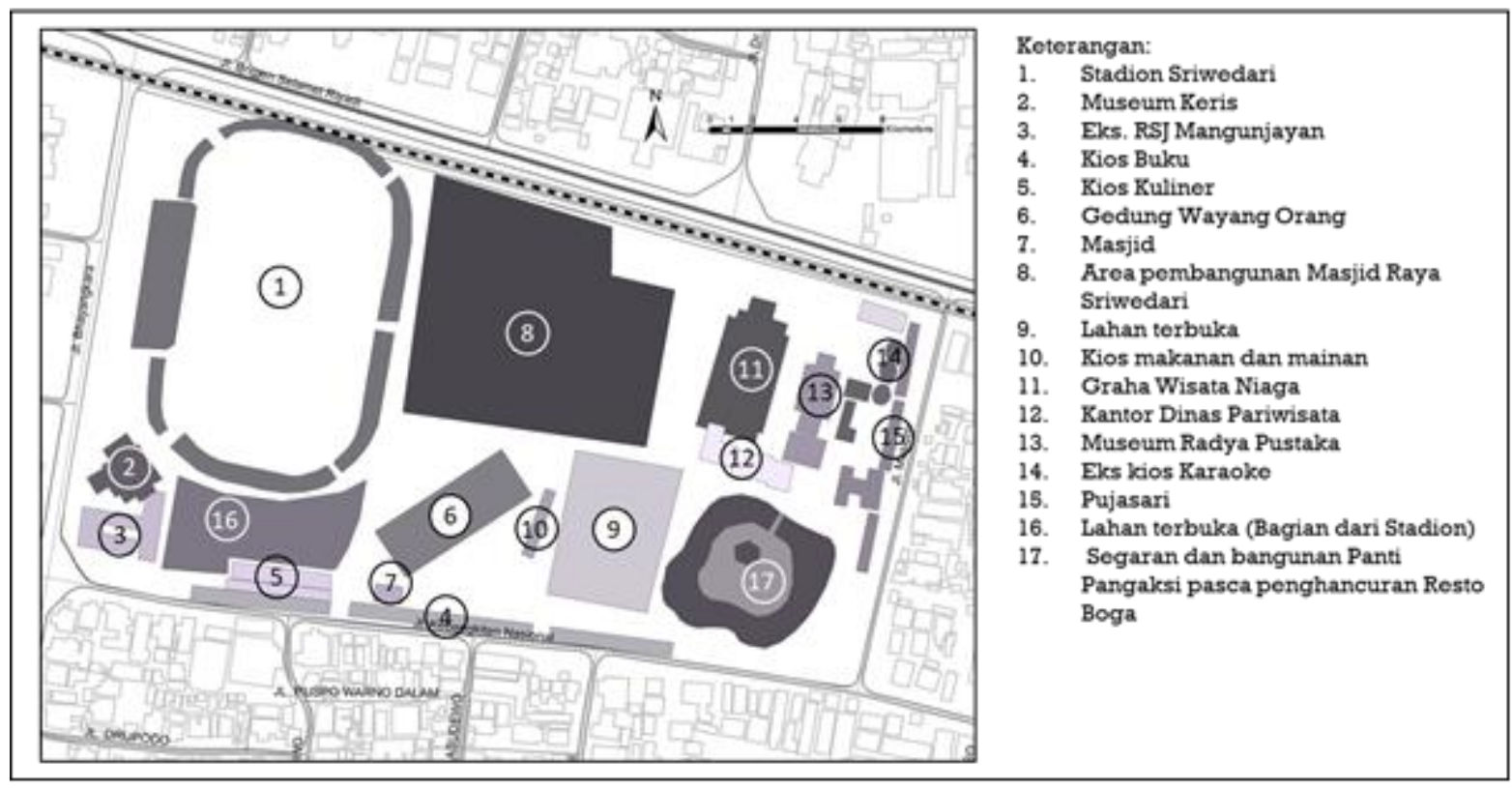

Gambar 7. Peta eksisting Taman Sriwedari.

\section{Kesimpulan}

Taman Sriwedari pada konsep awal pembangunannya, sudah merupakan ruang publik yang memiliki fasilitas cukup lengkap. Fungsi-fungsi yang ada sangat mendukung kawasan sebagai sebuah konsep ruang publik yang memfasilitasi interaksi masyarakat kota dalam suatu wadah yang dapat dinikmati bersama berbagai kalangan. Pada periode pertama, Taman Sriwedari menjadi sebuah ruang interaksi raja dengan rakyat serta berbagai etnis dapat bertemu dalam aktivitas-aktivitas seni dan budaya bersama, dalam hal ini adalah kebudayaan Jawa. Penggunaan ruang pada periode pertama erat dengan dengan kebijakan pembangunan oleh era pemerintahan Pakubuwono X. Sejalan dengan yang dinyatakan oleh Kim dan Min [39] bahwa salah satu tipe kekuatan yang mempengaruhi perkembangan (transformasi, karakterisasi, dan pembentukan) ruang publik adalah pengendalian oleh kekuasaan. Kemudian berkembang pula berbagai festival kebudayaan seperti Maleman yang menjadi icon Taman Sriwedari dan berawal dari tradisi yang juga berkaitan dengan kasunanan. Keberadaan museum dan kebun binatang juga menandai bahwa Taman Sriwedari tidak hanya berperan dalam hal pariwisata saja, namun juga dalam hal pendidikan.

Kemudian pada periode kedua, Taman Sriwedari berkembang sebagai sebuah ruang budaya dengan mempertahankan beberapa tradisi serta kesenian yang telah lahir pada periode pertama. Kebijakan pembangunan berpindah ke pemerintahan Republik Indonesia di bawah Pemerintah Kota Surakarta. Beberapa event besar, salah satunya pelaksanaan PON I juga dilaksanakan di Stadion Sriwedari pada masa itu. Beranjak pada periode ketiga, kebijakan pemerintah terkait dengan pembangunan dan kerja sama pihak ketiga membawa perubahan yang cukup signifikan pada Taman Sriwedari, kemudian berbagai tradisi mulai tidak rutin dilaksanakan. Hal-hal yang bersifat komersial dan modern perlahan mulai menghapus aktivitas-aktivitas yang bersifat tradisional dan memiliki nilai budaya. Scweinsberg, Darcy, dan 
Cheng dalam Smith [40] berargumen bahwa banyak ruang kota termasuk taman berada di bawah tekanan untuk memberikan nilai ekonomi kepada kota. Pada kasus Taman Sriwedari, selain untuk perbaikan taman, pada akhirnya aktivitas-aktivitas yang berkembang diupayakan untuk dapat memberikan keuntungan atau profit pada sektor pariwisata kota.

Perubahan sosial masyarakat yang interaksi sosialnya sudah berpindah ke sarana komunikasi modern juga turut mempengaruhi penggunaan Taman Sriwedari sebagai ruang publik. Dalam kasus wayang orang, misalnya, Hersapandi [25] berpendapat bahwa kemunduran wayang orang selain disebabkan oleh penurunan kualitas internal pengelolaan, juga dipengaruhi oleh faktor eksternal. Faktor tersebut antara lain banyaknya alternatif hiburan yang lebih variatif serta teknologi canggih, heterogenitas masyarakat Surakarta dan perkembangan kota yang cenderung urban, serta minimnya pendidikan muatan lokal kebudayaan jawa bagi generasi muda.

Berdasarkan Undang-Undang No. 11 Tahun 2010 tentang Cagar Budaya [10], seharusnya Taman Sriwedari merupakan satu kesatuan kawasan cagar budaya karena di dalamnya terdapat lebih dari 2 (dua) bangunan yang berstatus cagar budaya. Tanpa melihat status pun, setiap komponen di Taman Sriwedari sebenarnya sudah memiliki nilai-nilai budaya dan sejarah. Merujuk pada pendapat Jappelli dalam Bolici \& Gambaro [41], memulihkan aspek budaya kota dan ruang publiknya, dengan mengoperasikan pada kelayakan historis dan bagaimana ruang digunakan, adalah hal yang sangat mendasar. Sehingga gambaran mengenai masa lalu dapat direpresentasi dalam ruang-ruang kota. Pada realisasinya, kini Taman Sriwedari dikembangkan sebagai sebuah konsep baru dengan penambahan sarana peribadatan yang cukup besar dan mendominasi lahan kawasan. Taman Sriwedari merupakan cultural heritage yang perlu dipertahankan tidak hanya keberadaan bangunan lamanya saja, melainkan harmonisasi dari segi fungsi dan aktivitas di dalamnya. Konsep ruang publik Taman Sriwedari saat sudah jauh dari konsep awal yang diinisiasi oleh Paku Buwono X. Nilai seni dan budaya yang melekat pada Taman Sriwedari sudah tergantikan dengan aktivitas komersial yang akhirnya juga kalah dengan modernisasi lainnya yang berkembangan di wilayah lain. Dalam rangka revitalisasi taman, maka perlu diupayakan untuk mengembalikan nilai-nilai historis taman melalui penghidupan kembali aktivitas-aktivitas yang dahulu pernah berkembang dan membesarkan nama Taman Sriwedari.

Berbeda dengan penelitian sebelumnya yang sebagian besar menggunakan data umum dan data tahun berjalan penelitian, penelitian ini menggambarkan kondisi sejak awal pengembangan taman. Diharapkan data perkembangan spasial ini dapat menjadi input bagi penelitian selanjutnya yang bersifat rekomendasi re-design atau kajian mengenai konteks tertentu yang kaitannya dengan fungsi dan peran ruang publik (sosial dan budaya misalnya). Mengingat bahwa penelitian ini hanya terbatas pada data spasial sebelum ruang mengalami revitalisasi, pada penelitian berikutnya kami berharap penelitian dapat mengarah ke bagaimana revitalisasi dapat berpengaruh kepada perkembangan ruang publik bersejarah dan bagaimana efektifitas ruang publik pasca revitalisasi tersebut untuk tahun berjalan kedepannya. 


\section{Referensi}

[1] Jokilehto J. Definition of Cultural Heritage: References to Documents in History. ICCROM Work Gr'Heritage Soc 2005:45.

[2] Buckland M. Cultural Heritage (Patrimony): An Introduction. Rec Arch Mem Sel Pap from Conf Sch Rec 2015;15:250-60.

[3] Carr S, Francis M, Rivlin LG, Stone AM. Public Space. Australia: Press Syndicate of University of Cambridge; 1992.

[4] Darmawan E. Ruang Publik dan Kualitas Ruang Kota. Semin. Nas. PESAT, Jakarta: Universitas Gunadarma; 2005, p. 35-43.

[5] Charter of Public Space. II Bienn Public Sp 2013.

[6] Carmona M, de Magalhães C, Hammond L. Public Space: The Dimensions of Management. London: Routledge; 2008. https://doi.org/10.4324/9780203927229.

[7] Dewi EP. Analisis Ruang Terbuka Publik Bersejarah dalam Rangka Revitalisasi Kota Tua Jakarta. Institut Pertanian Bogor, 2009.

[8] Harjana Y. Babad Taman Sriwedari. Surakarta: Lim Swan Bi; 1926.

[9] Buwono XII P, Mutholi'in A. Karaton Surakarta: A Look into the Court of Surakarta Hadiningrat, Central Java. Singapore: Marshall Cavendish; 2005.

[10] Undang-undang Republik Indonesia Nomor 11 Tahun 2010 tentang Cagar Budaya n.d.

[11] Al-Houdalieh SH, Sauders RR. Building Destruction: The Consequences of Rising Urbanization on Cultural Heritage in the Ramallah Province. Int J Cult Prop 2009;16:123. https://doi.org/10.1017/S0940739109090043.

[12] Arifianto R. Redesain Taman Sriwedari sebagai Pusat Konvensi dan Pameran di Kota Surakarta. Universitas Diponegoro, 2014.

[13] Iswari SA, Nurini. Efektivitas Taman Sriwedari Sebagai Ruang Publik di Kota Surakarta. Tek PWK 2014;3:671-80.

[14] Mulyanto DW. Eksistensi Tata Ruang Keraton Kasunanan Surakarta Hadiningrat Tahun 2008. Universitas Sebelas Maret, 2008.

[15] Andriani MN, Ali MM. Kajian Eksistensi Pasar Tradisional Kota Surakarta. J Tek PWK 2013;2:252-69.

[16] Said RM. Babad Sala. Surakarta: Rekso Pustoko Mangkunagaran; 1984.

[17] Universiteit Leiden. Maps (KITLV) n.d.

[18] Radjiman. Toponimi Kota Surakarta dan Awal Berdirinya Kasunanan Surakarta Hadiningrat. Surakarta: Universitas Sebelas Maret; 2002.

[19] Raap OJ. Kota di Djawa Tempo Doeloe. Jakarta: Kepustakaan Populer Gramedia; 2017.

[20] Majalah Kejawen, edisi 28 Maret 1928 n.d.

[21] Dipokusumo K. Komunikasi Personal 2019.

[22] Kaptein NJG. Islam, Colonialism and the Modern Age in the Netherlands East Indies: A Biography of Sayyid 'Uthman (1822-1914). Leiden: Brill; 2014.

[23] Kuntowijoyo. Raja, Priyayi, dan Kawula: Surakarta, 1900-1915. Yogyakarta: Ombak; n.d.

[24] Harian De Indische Courant. Boedi Oetomo, edisi 23 Mei 1933 n.d.

[25] Hersapandi. Wayang Wong Sriwedari: Dari Seni Istana menjadi Seni Komersial. Yogyakarta: Yayasan Untuk Indonesia; 1999.

[26] Suparno I. Sala Membangun: Menyambut peresmian purna pemugaran Stadion 
Sriwedari sebagai monumen PON-I dan Hari Olahraga Nasional 9 September 1983. Surakarta: Tim Penyusun Buku Kenang-Kenangan Peresmian Pemugaran Sriwedari; 1983.

[27] Harian Kompas. Taman Sriwedari Solo, edisi 14 November 1982 n.d.

[28] Puspitasari P, Djunaedi A, Sudaryono, Putra HSA. Cyclical Changes of Space: The Phenomena of Space Changes in Historic-Religious Kampung Luar Batang, Jakarta, Indonesia. Asian J Environ Stud 2018;3:33-46. https://doi.org/10.21834/ajebs.v3i6.237.

[29] Luwes UHG. Sejarah Perkembangan Bioskop di Surakarta Tahun 1950-1979. Universitas Sebelas Maret, 2010.

[30] Departemen Dalam Negeri Direktorat Jenderal Agraria. Peta Taman Sriwedari Tahun 1945-1946 n.d.

[31] Mulyadi MH. Runtuhnya Kekuasaan Kraton Alit: Studi Radikalisasi " "Wong Sala" dan Kerusuhan Mei 1998 di Surakarta. Surakarta: Lembaga Pengembangan Teknologi Pedesaan; 1999.

[32] Sukamto J. Komunikasi Personal 2019.

[33] DPU. Peta Taman Sriwedari Eksisting 2015.

[34] Harian Kompas. Maleman Sriwedari Tambah Sepi, edisi 10 April 1990 n.d.

[35] Harsini. Komunikasi Personal 2019.

[36] Harian Kompas. Kabut Jingga di Atas Segaran: Keprihatinan soal Sriwedari Lewat Tari, edisi 18 Desember 2003 n.d.

[37] Harian Kompas. Jazz in Segaran, edisi 25 September 2006 n.d.

[38] Harian Kompas. Jazzin' Segaran Gugah Kesadaran Kolektif, edisi 9 Oktober 2006 n.d.

[39] Kim HJ, Min B. Power and Public Space: A Historical Observation of Seoul Plaza. Sustain 2019;11:1-17. https://doi.org/10.3390/su11051379.

[40] Smith A. Paying for parks. Ticketed Events and The Commercialisation of Public Space. Leis Stud 2018;37:533-46. https://doi.org/10.1080/02614367.2018.1497077.

[41] Bolici R, Gambaro M, Giordano C. The Regaining of Public Spaces to Enhance the Historic Urban Landscape. J Public Sp 2017;2:45-56. https://doi.org/10.5204/jps.v2i1.49. 